C. E. Suh • R. S. J. Sparks • J. G. Fitton •

S. N. Ayonghe $\cdot$ C. Annen - R. Nana - A. Luckman

\title{
The 1999 and 2000 eruptions of Mount Cameroon: eruption behaviour and petrochemistry of lava
}

Published online: 16 February 2005

(C) Springer-Verlag 2005

\section{Bull Volcanol (2003) 65:267-281}

We have discovered an error in some of the data reported in Suh et al. (2003) in relation to the trace element compositions of Mount Cameroon. Comparison was made between the older $20^{\text {th }}$ Century lavas and the 1999 and 2000 lavas. The samples described by Fitton et al. (1983) were re-analysed at the same time as we analysed the 1999 and 2000 lavas because there have been changes in the standardisation of trace elements, in particular $\mathrm{Nb}$. The analyses reported in Fitton et al. (1983) were calibrated against an international standard (BE-N) with a reported value of $\mathrm{Nb}=100 \mathrm{ppm}$ (Govindaraju 1989). This standard was reassessed in 1994 and a value of $105 \mathrm{ppm}$ was adopted (Govindaraju 1994), although Jochum et al.

The online version of the original article can be found at http:// dx.doi.org/10.1007/s00445-002-0257-7

C. E. Suh · S. N. Ayonghe

Department of Geology and Environmental Science,

University of Buea,

P.O. Box 63, Buea, South West Province, Cameroon

R. S. J. Sparks $(\bowtie) \cdot$ C. Annen

Department of Earth Sciences,

University of Bristol, Wills Memorial Building,

Queens Road, Bristol, BS8 1RJ, UK

e-mail: steve.sparks@bristol.ac.uk

Tel.: +44-117-9545419

Fax: +44-117-9253385

J. G. Fitton

Department of Geology and Geophysics, Grant Institute,

University of Edinburgh,

West Mains Road, Edinburgh, EH9 3JW, UK

R. Nana

Department of Earth Sciences, Faculty of Science,

University of Yaounde I,

B.P. 812, Yaounde, Cameroon

\section{A. Luckman}

Department of Geography,

University of Wales Swansea,

Singleton Park, Swansea, SA2 8PP, UK
(1990) obtained a value of $116 \pm 5$ ppm using spark-source mass spectrometry. The $\mathrm{Nb}$ and $\mathrm{Zr}$ values obtained by Jochum et al. (1990) for several international standards give better XRF calibration lines (smaller mean square of weighted deviates) than do the values recommended by Govindaraju (1994) and so the Jochum et al. (1994) Nb and $\mathrm{Zr}$ values are now routinely used for calibration in the Edinburgh XRF laboratory. Unfortunately the old rather than the new recalibrated analyses were inadvertently used in Fig. 7 of Suh et al. (2003), which led us to the conclusion that the 1982 and 1999-2000 lavas form distinct trends on a plot of $\mathrm{Nb}$ against $\mathrm{Zr}$. When the new recalibrated analyses are plotted (Fig. 1) the 1982 lavas plot on the same trend as the 1999 and 2000 lavas. We report these new analyses in Table 1.

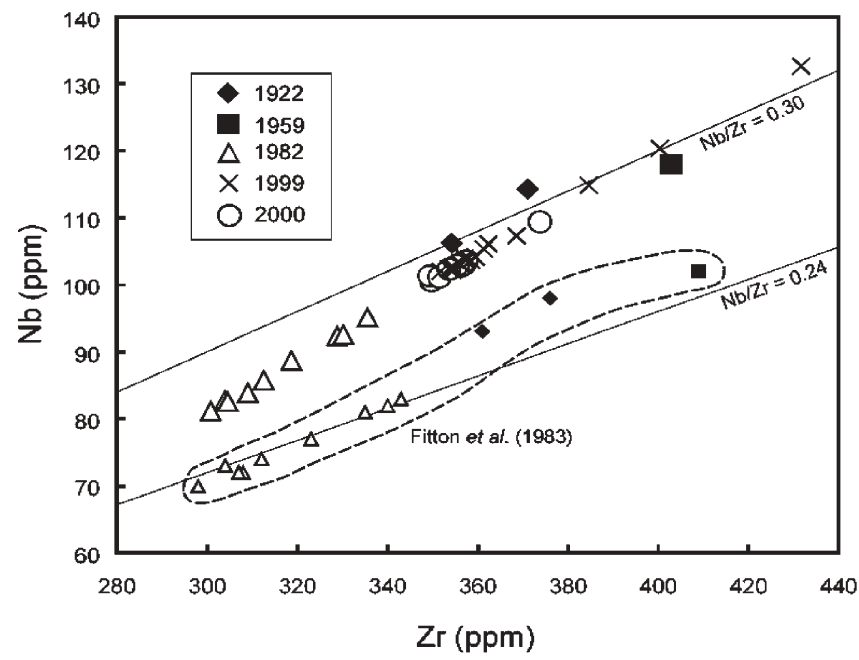

Fig. 1 New $\mathrm{Nb}$ and $\mathrm{Zr}$ data for the pre-1999 lavas from $\mathrm{Mt} \mathrm{Ca}$ meroon plotted with the data for the 1999 and 2000 eruptions reported by Suh et al. (2003). The old pre-1999 data (small symbols, from Fitton et al. (1983) are plotted for comparison. Analytical precision for the new analyses is less than the size of the data symbols 


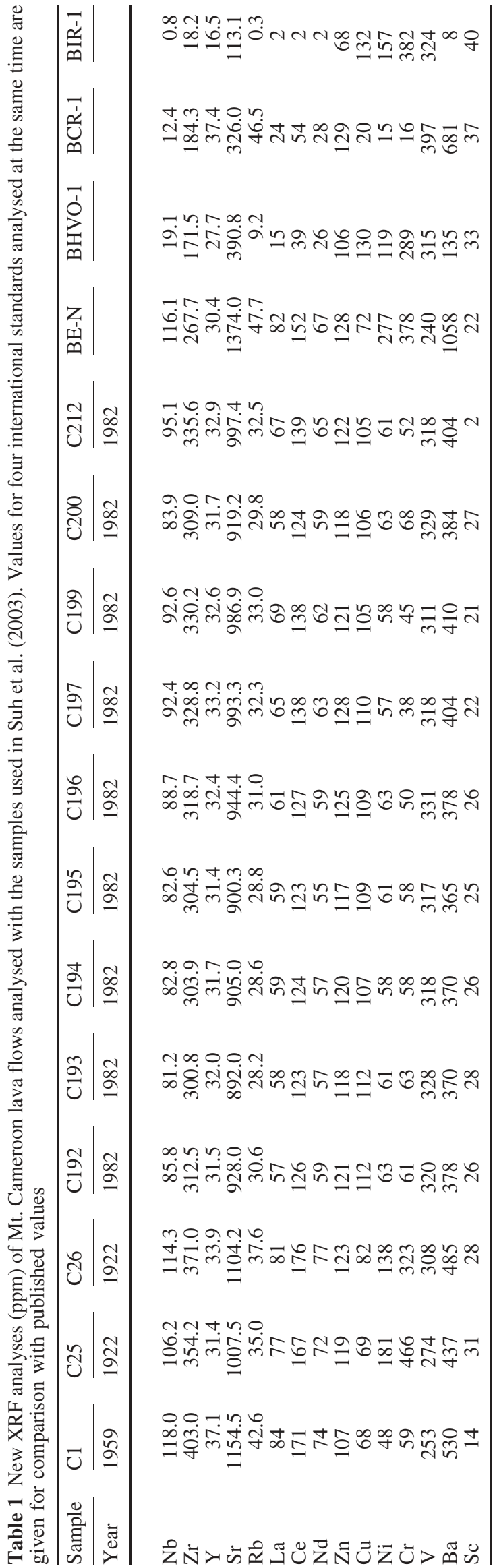

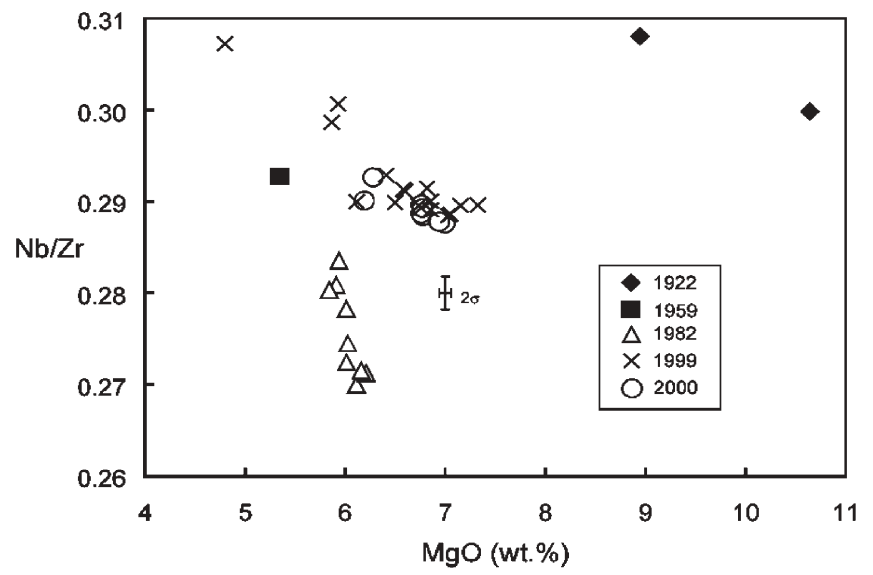

Fig. $2 \mathrm{Nb} / \mathrm{Zr}$ variation with degree of magma evolution (falling $\mathrm{MgO}$ ) for the historic Mt Cameroon lavas. All the analyses were obtained on a single high-precision XRF calibration. Error bars represent typical $2 \sigma$ analytical precision

At first sight, the new data plotted in Fig. 1 appear to show that the 1982, 1999 and 2000 Mt Cameroon lavas could have evolved along a liquid line of descent from a common parental magma through fractional crystallisation. The data array could, for example, be generated by $40 \%$ crystallisation of phases with bulk $\mathrm{D}_{\mathrm{Nb}}=0.005$ and bulk $\mathrm{D}_{\mathrm{Zr}}=0.28$; partition coefficients consistent with a crystallising assemblage dominated by aluminous augite (Wood and Trigila 2001). This simple fractional crystallisation model conflicts with the conclusions of Suh et al. (2003) that the 1982 and 1999-2000 lavas evolved from separate batches of primary magma. The fractional crystallisation model predicts that $\mathrm{Nb} / \mathrm{Zr}$ should vary systematically with indices of differentiation such as $\mathrm{MgO}$ content, and this can easily be tested. Figure 2 shows variation of $\mathrm{Nb} / \mathrm{Zr}$ with $\mathrm{MgO}$ content and it is clear from this plot that the magmas represented by lavas erupted in the 1982, 1999 and 2000 eruptions cannot have evolved from a single parent. In particular, the steep rise in $\mathrm{Nb} / \mathrm{Zr}$ in the 1982 lavas accompanied by only a very small fall in $\mathrm{MgO}$ content cannot result from fractional crystallisation, but is more likely the result of mixing between independently derived magma batches as suggested by Fitton et al. (1983). Thus the conclusions of Suh et al. (2003) are unaffected by our error in plotting the wrong data in Fig. 7 of that paper.

\section{References}

Fitton JG, Kilburn CRL, Thirlwell MF, Hughes DJ (1983) 1982 eruption of Mount Cameroon, West Africa. Nature 306:327332

Govindaraju K (1989) 1989 compilation of working values and sample description for 272 geostandards. Geostandards Newsletter 13: Special Issue, 1-113

Govindaraju K (1994) 1994 compilation of working values and sample description for 383 geostandards. Geostandards Newsletter $18: 1-158$ 
Jochum KP, Seufert HM, Thirlwall MF (1990) High-sensitivity Nb analysis by spark-source mass spectrometry (SSMS) and calibration of XRF Nb and Zr. Chemical Geology 81:1-16

Suh CE, Sparks RSJ, Fitton JG, Ayonghe SN, Annen C, Nana R, Luckman A (2003) The 1999 and 2000 Eruptions of Mount Cameroon: Eruption Behaviour and Petrochemistry of Lava. Bull Volcanol 65:267-281
Wood BJ, Trigila R (2001) Experimental determination of aluminous clinopyroxene-melt partition coefficients for potassic liquids, with application to the evolution of the Roman province potassic magmas. Chemical Geology 172:213-223 